\author{
JURNAL RESPIRASI \\ JR
}

Vol. 5 No. 3 September 2019

\title{
Seorang Wanita dengan Cor Pulmonale Terkait Silikosis
}

\author{
Abdul Rahman Bahmid*, Helmia Hasan \\ Departemen Pulmonologi dan Ilmu Kedokteran Respirasi, Fakultas Kedokteran, Universitas Airlangga/RSUD Dr. Soetomo, \\ Surabaya, Indonesia
}

\begin{abstract}
Background: Silicosis is a fibrosing disease of the lungs caused by the inhalation of crystalline silica. Silicosis can cause pulmonary function impairment due to structural changes in lung parenchym. Parenchymal damage can cause pulmonary arterial hypertension. Case: Woman, 47 years old with history of working in rubber factory for 2 years 15 years ago, presented with shortness of breath especially during activity, swelling in both legs since 1 month ago, decreased of appetite in 2 months. From chest $X$-ray examination there is nodule in parahiler right hemithorax and consolidation in paracardial of both hemithorax. HRCT of thorax showed consolidation with multiple calcifications in inferior lobes of both lungs, multifocal ground glass opacity in anterior-posterior segment of superior and inferior lobes of the right lung. Echocardiography examination revealed tricuspid valve regurgitation, right ventricular dilation and decreased of right ventricular systolic volume. As much as 108.96 SiO2 silica was found on spectrophometric examination of induced sputum. Conclusion: silicosis is a progressive and irreversible fibrotic lung disease. Cor Pulmonale is a secondary development of pulmonary hypertension that causes increase of pulmonary vascular resistance $(P V R)$ and pulmonary arterial pressure $(P A P)$ associated with pulmonary fibrosis
\end{abstract}

Keywords: silicosis, pulmonary hypertension, Cor pulmonale

Correspondence: Abdul Rahman Bahmid, Departemen Pulmonologi dan Ilmu Kedokteran Respirasi, Fakultas Kedokteran, Universitas Airlangga/RSUD Dr. Soetomo. Jl. Mayjen. Prof Dr. Moestopo 6-8 Surabaya 60286. E-mail: wbahmid@gmail.com

\section{PENDAHULUAN}

Silikosis adalah penyakit fibrosis paru yang disebabkan oleh inhalasi kristal silika (silicon dioksida). Silika adalah bahan yang dapat ditemukan dimana-mana yang merupakan komponen utama kerak bumi. Terdapat tiga bentuk utama kristal silika yang menyebabkan cidera paru yaitu quartz, kristobalit, dan tridimit. Quartz merupakan silika yang paling sering ditemukan pada sebagian besar batu, termasuk granit dan batu pasir. ${ }^{1}$

Masalah utama dalam silikosis adalah gangguan fungsi paru karena perubahan struktural parenkim paru dan fibrosis paru, yang dapat menyebabkan disfungsi pernapasan baik bersifat restriktif ataupun obstruktif. Kerusakan pada parenkim paru menyebabkan hipertensi arteri pulmonal dan peningkatan tekanan di ventrikel kanan. $^{2}$

Hipertensi pulmonal (HP) merupakan peningkatan resistensi sirkulasi paru pada penyakit paru kronis yang menyebabkan pembesaran ventrikel kanan, dengan gejala yang sering ditemukan yaitu sianosis, edemaa perifer, tanda-tanda pembesaran jantung kanan dan peningkatan vena sentral. ${ }^{3}$ Pulmonary arterial hypertension (PAH) adalah salah satu penyebab hipertensi pulmonal yang ditandai dengan tekanan arteri pulmonalis rata-rata yang lebih dari $25 \mathrm{mmHg}$ saat $<15$
mmHg. Pada keadaan normal sirkulasi paru memiliki istrahat dengan pulmonary capillary wedge preasure resistensi yang rendah, hal ini karena pembuluh darah paru memiliki kapasitas yang tinggi dengan kemampuan menampung seluruh cardiac output pada tekanan arteri yang rendah., 4

Saat ini istilah cor pulmonale umumnya mengacu pada kelainan struktur dan fungsi jantung kanan yang disebabkan oleh penyakit paru dan/atau hipoksemia, termasuk penyakit parenkim paru, gangguan ventilasi atau high-altitude hypoxemia. Cor pulmonale merupakan perkembangan sekunder dari hipertensi pulmoner, yang ditandai oleh peningkatan resistensi pembuluh darah paru dan tekanan arteri pulmonalis yang menyebabkan peningkatan afterload ventrikel kanan, dan akhirnya berkembang menjadi kegagalan ventrikel kanan. ${ }^{6}$

\section{KASUS}

Seorang wanita umur 47 tahun, suku jawa, pekerjaan ibu rumah tangga datang dengan keluhan sesak napas dialami sejak 1 bulan hilang timbul, dan memberat 1 minggu terakhir. Sesak terutama saat beraktifitas. Batuk sekali-sekali, dengan dahak 

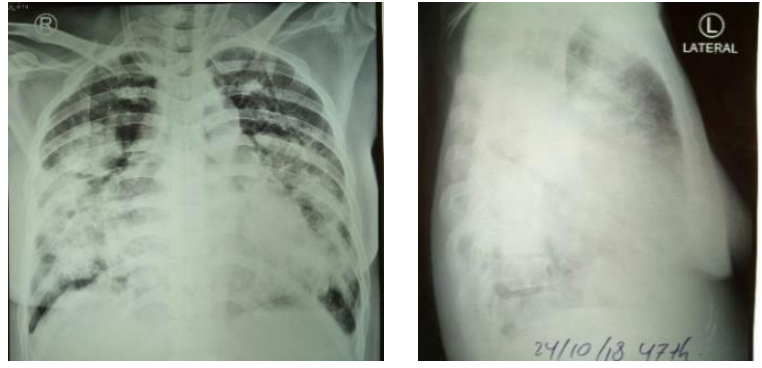

Gambar 1. Foto toraks anteroposterior - lateral S

warna putih. Bengkak pada kedua kaki sejak lebih dari 1 bulan yang lalu. Riwayat penurunan nafsu makan dalam 2 bulan ini, penurunan berat badan dan keringat malam tidak ada.

Tidak ada riwayat asma, TB paru, dan DM. Pasien pernah bekerja di pabrik karet sekitar 15 tahun yang lalu selama 2 tahun.

Pada pemeriksaan fisik regio kepala/leher terdapat peningkatan JVP $(5 \mathrm{~cm}+5 \mathrm{~cm})$, pada regio toraks didapatkan inspeksi simetris, pergerakan dada simetris, palpasi: fremitus raba meningkat di $2 / 3$ bawah hemitoraks kanan, perkusi : redup di $2 / 3$ bawah kedua hemitoraks, auskultasi: bronkovesikuler di 2/3 bawah kedua hemitoraks, ronki di $2 / 3$ bawah kedua hemitoraks. Batas jantung kanan sulit dievaluasi. Pada regio ekstremitas ditemukan edema di kedua ekstremitas bawah.

Pemeriksaan electrocardiography (ECG) menunjukkan hasil irama sinus, axis RAD, RVH, T inversi V1-V6, II, III, AVF.

Pemeriksaan foto toraks menunjukkan gambaran nodul di hemitoraks kanan disertai infiltrat di parakardial hemitoraks kanan dan kiri, dapat merupakan 1) Pnemonia, 2) massa paru.

Pada HRCT toraks tampak konsolidasi dengan multiple kalsifikasi didalamnya di segmen superior dan segmen posterobasal lobus inferior paru kanan dan kiri dengan gambaran emfisema pada segmen anterior lobus superior paru kanan kiri, tampak fibrosis di lapangan paru kanan dan kiri, disertai tenting hemidiafragma kanan kiri, tampak multifocal ground glass opacity di segmen anteriorposterior lobus superior dan segmen posterobasal lobus inferior paru kanan, jantung membesar ke kanan dan kiri dengan CTR 68\%. Tidak tampak atelektasis paru. Kesan temuan gambaran silikosis, dan kardiomegali.

Pemeriksaan histopatologi dari bahan core biopsi menunjukkan potongan jaringan tanpa epitel, stroma jaringan ikat fibrous dengan infiltrasi sel-sel radang limfosit, histiosit. Tampak fokus membentuk granuloma. Kesimpulan : radang granulomatik. Hasil pemeriksaan fungsi paru menunjukkan nilai FVC: $55 \%$ dan $\mathrm{FEV}_{1} / \mathrm{FVC}: 70 \%$ dengan kesimpulan restriksi sedang dan obstruksi ringan.

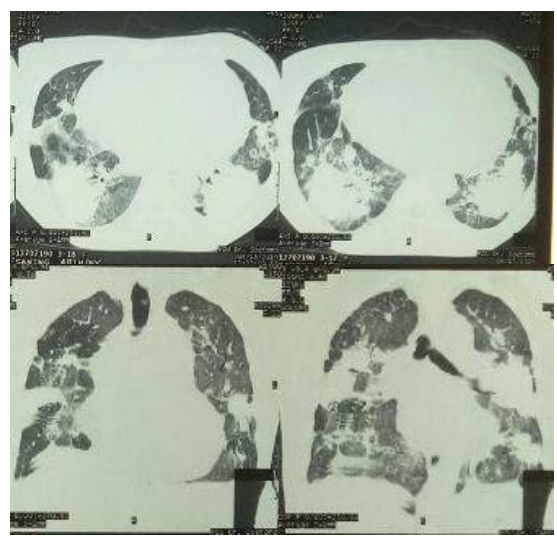

Gambar 2. HRCT toraks

Hasil pemeriksaan smear putum tidak ditemukan BTA, dan hasil pemeriksaan geneXpert: M.tb not detected. Pemeriksaan echocardiography dengan kesimpulan: 1) Katup-katup: - TR berat, PR sedang. 2) Dimensi ruang jantung: LA normal, LV normal, RA dilatasi, RV dilatasi. 3) Fungsi sistolik LV normal, fungsi sistolik RV menurun. 4) Analisis segmental LV normokinetik. 5) Terdapat LV concentric remodelling. Parameter hemodinamik: PCWP 8,25 mm/Hg, Klinikal diagnosis mendukung gambaran cor pulmonale.

Pasien ini memiliki resiko tinggi untuk dilakukan FOB, sehingga kami tidak dapat melakukan pemeriksaan sampel dari bahan bronchoalveolar lavage (BAL). Sebagai alternatifnya kami melakukan induksi sputum untuk pemeriksaan spektrofometri dan kultur M.tb. Hasil pemeriksaan spektrofotometri dari bahan sputum induksi menunjukkan silika sebanyak 108,96 ppm SiO2, dan untuk pemeriksaan kultur M.tb tidak didapatkan kuman M.tb.

\section{DISKUSI}

Silikosis adalah penyakit fibrosis paru yang disebabkan oleh inhalasi kristal silika. Terdapat tiga bentuk utama kristal silika yang menyebabkan cidera paru yaitu quartz, kristobalit, dan tridimit. Bentuk silika yang paling sering menyebabkan silikosis adalah bentuk quartz (free silica), yang umumnya terdapat pada berbagai jenis bebatuan seperti batu pasir, granit dan batu tulis dengan jumlah yang bervariasi dari $20 \%$ hingga $100 \% \cdot{ }^{1,8}$

\section{Epidemiologi}

Banyak faktor yang mempengaruhi luasnya silikosis pada individu yang terpapar, tetapi paparan kumulatif (intensitas dan durasi paparan dinyatakan sebagai mg/m3-tahun), dan lama paparan dari paparan pertama dianggap sebagai faktor yang berkontribusi terhadap kejadian silikosis. Perkiraan persentase silikosis dalam 11 studi di tiga tingkat paparan silika kumulatif sangat bervariasi, dari $0,4 \%$ hingga $28 \%$ pada $2 \mathrm{mg} / \mathrm{m} 3$ tahun, dan dari $2 \%$ hingga $92 \%$ pada $4 \mathrm{mg} / \mathrm{m} 3$-tahun. Studi cross-sectional pada pekerja yang terpapar saat ini kurang memperhatikan adanya risiko penyakit, karena mungkin pekerja yang terkena dampak telah berhenti bekerja atau penyakitnya berkembang setelah 
meninggalkan pekerjaanya. $^{9}$ Pada tahun 2007 Occupational Safety and Health Administration (OSHA) memperkirakan lebih dari 2 juta pekerja terpapar silika di industri umum, konstruksi dan maritim. ${ }^{10}$ Menurut data Surveillance of Work-related and Occupational Respiratory Disease (SWORD) di Inggris dari tahun 1996 sampai 2017 tercatat 216 kasus silokosis, dengan umur rata-rata 61 tahun dan mayoritas laki-laki. ${ }^{11}$

Data di RSUD dr. Soetomo pada tahun 2018 tercatat hanya 1 kasus pasien dengan silikotuberkulosis pada laki-laki umur 36 tahun dengan pekerjaan pengasah batu marmer. ${ }^{12}$ Pada kasus ini seorang wanita umur 47 tahun dengan riwayat pekerjaan karyawan di pabrik karet 15 tahun yang lalu, dengan hasil pemeriksaan HRCT toraks dengan gambaran silikosis dan pada pemeriksaan spektrofotometri pada spesimen sputum induksi terdapat silika sebanyak 108,96 ppm $\mathrm{SiO}_{2}$.

\section{Faktor risiko}

Silikosis sering menjadi penyakit utama pada pekerja yang terpapar debu silika. Menurut NIOSH pekerja yang memiliki risiko tinggi antara lain konstruksi, pengeboran batu di permukaan atau di bawah tanah. Pengecoran juga merupakan sumber utama debu silika. Laporan terbaru menunjukkan risiko silikosis untuk pekerja yang berhubungan dengan perbaikan, rehabilitasi, atau pembongkaran struktur beton dan jalan. Kejadian silikosis lebih sedikit pada pekerja yang memproduksi denim dengan sandblasting, pengukir batu, produsen meja granit, teknisi gigi, perhiasan yang menggunakan cetakan kapur. Silikosis sering ditemukan akibat paparan menahun dan risiko keparahan tergantung pada tingkat paparan. ${ }^{6}$ Dalam beberapa tahun terakhir kasus silikosis juga terjadi pada pekerja batu buatan yang terkena debu yang dihasilkan dari pembuatan dekorasi interior, kitchenset, dan kamar mandi yang mengandung kristal silika antara $70 \%$ hingga 90\%. ${ }^{12}$ Terdapat satu laporan kasus silikosis pada pekerja pabrik karet yang bekerja selama 8 tahun di laporkan oleh Graham dan Gaesler pada tahun $1965 .{ }^{13}$

Pada kasus ini seorang wanita yang pernah bekerja di pabrik karet 15 tahun yang lalu selama 2 tahun, berdasarkan pemeriksaan CT scan toraks dan spektrofometri dari spesimen sputum induksi didiagnosa silikosis.

\section{Patogenesis}

Terdapat beberapa bentuk patologis dari silikosis antara lain simple (nodular) silikosis, progressive massive fibrosis (PMF), silikoproteinosis, dan fibrosis interstitial difus. Nodul silikosis biasanya berada di lobus atas paru, disertai pembesaran kelenjar getah bening hilus dan peribronkial. Pada silikosis PMF nodul paru menjadi confluent dan membentuk lesi ukuran $1 \mathrm{~cm}$ atau lebih. ${ }^{14}$ Lesi pada silikosis biasanya berupa lesi granulomatosa dan lesi fibrotik yang terjadi karena akumulasi partikel silika yang terhirup. Debu kristal silika menyebabkan akumulasi cairan dan jaringan parut di paru yang dapat mengurangi kemampuan bernapas. Silika dapat menginduksi aktivasi makrofag yang merupakan salah satu faktor penting respon peradangan di paru. Partikel silika juga dapat menghasilkan reaktif oksigen species (ROS) dan reaktif nitrogen spesies (RNS), yang memicu berbagai reaksi biologis yang menyebabkan kerusakan jaringan. ${ }^{15}$

ROS dan RNS dihasilkan oleh partikel silika yang memicu serangkaian mekanisme seperti meningkatkan ekspresi sitokin inflamasi termasuk tumor necrosis factor- $\alpha$ (TNF- $\alpha$ ), interleukin-1 $\beta$ (IL $1 \beta)$ dan transforming growth factor- $\beta$ (TGF- $\beta$ ). Sitokin inflamsi ini memicu respons imun dan juga mengaktifkan umpan balik yang menarik lebih banyak sel inflamasi ke tempat reaksi. ROS dan RNS akan mengaktifkan jalur persinyalan sel, termasuk jalur MAP kinase dan mengaktifkan faktor transkripsi spesifik (NFkB), yang memediasi mekanisme peradangan dan kerusakan jaringan. Silika tidak mudah dieliminasi oleh enzim lisosom makrofag dan secara langsung bersifat sitotoksik terhadap makrofag dan leukosit polimorfonuklear. Makrofag yang menelan partikel silika menjadi nekrosis dan melepaskan lisosom dan ROS, yang menyebabkan rekrutmen lokal leukosit polimorfonuklear dan kerusakan jaringan. ${ }^{16}$ Selain makrofag alveolar, sel-sel radang lainnya seperti neutrophil, limfosit $\mathrm{T}$ dan sel mast yang terakumulasi di dearah interstitial memiliki peran penting terjadinya fibrosis. Silika dapat menginduksi fibrogenesis akibat cidera pada sel epitel tipe I dan diikuti oleh hyperplasia sel tipe II. ${ }^{15}$

Nodul silikosis dalam parenkim paru biasanya berada di lobus atas, dan memiliki derajat kalsifikasi yang bervariasi, dari diameter yang hanya beberapa milimeter hingga lebih dari satu sentimeter. PMF atau complicated silikosis adalah kondisi dimana lesi paru menyatu membentuk massa paru $2 \mathrm{~cm}$ atau lebih. PMF dapat berkembang menjadi nekrosis sentral dengan kavitasi, yang memungkinkan terjadinya infeksi sekunder berbagai organisme mikobakteri termasuk mycobacterium tuberculosis, mycobacterium kansasii, mycobacterium intraseluler. ${ }^{17}$

Nodul dapat terus meluas hingga ke bagian tengah dan basal paru. PMF dapat berkembang dengan bertambahnya durasi dan intensitas paparan. PMF ditandai dengan nodul yang membentuk massa fibrous dengan ukuran satu hingga beberapa sentimeter. Lobus atas dapat sepenuhnya diganti oleh massa yang menghilangkan fisura inter lobaris. Pada kasus silikosis kronis dan PMF dapat terjadi cor pulmonale. ${ }^{9}$ 


\section{Hipertensi Pulmoner terkait penyakit paru}

Mekanisme dasar terjadinya HP pada penyakit paru belum sepenuhnya dipahami karena bersifat multifactor dan bervariasi dengan penyakit paru yang mendasarinya. Kemungkinan kerusakan endotel pembuluh darah disebabkan oleh beberapa faktor seperti hipoksemia dan inflamasi yang menyebabkan disfungsi endotel dan perubahan struktur vaskuler. Keadaan ini dapat menyebabkan peningkatan pulmonary vascular resistance (PVR) dan peningkatan pulmonary artery pressure (PAP). ${ }^{6}$

Banyak faktor yang menyebabkan peningkatan PVR pada penyakit paru kronis, namun sejauh ini faktor utama adalah hipoksia alveolar. Terdapat dua mekanisme hipoksia alveolar, yaitu hipoksia akut yang menyebabkan vasokonstriksi paru, dan hipoksia kronis yang berlangsung lama menyebabkan perubahan struktural pada pulmonary vascular bed (remodelling vaskuler paru). Hypoxic pulmonary vasoconstriction merupakan salah satu kondisi yang menyebabkan peningkatan PVR dan PAP, vasokonstriksi ini terlokalisasi pada precapillary arteri kecil. Peningkatan PVR pada fibrosis paru disebabkan oleh faktor anatomi, yaitu berkurangnya pulmonary vascular bed atau kompresi arteriol dan kapiler karena proses fibrosis. ${ }^{18}$

\section{Remodelling vaskuler paru}

Karakteristik yang terlihat pada HP terkait penyakit paru yang juga terlihat pada $\mathrm{PAH}$ adalah ekstensi dari otot polos arteriol paru kurang dari 80 um, yang tidak ditemukan pada paru sehat. Hal ini disebut "muskularisasi" dan ditandai dengan sel-sel otot polos antara dua lapisan lamina elastis. Muskularisasi dapat terjadi akibat hipertrofi dan ploriferasi otot polos yang ada dan perkembangan sel otot polos baru. ${ }^{6}$

Berbagai bentuk dari HP terjadi karena remodelling arteri atau remodelling vena atau keduanya. Pada penyakit paru kronis termasuk ILD, terdapat dua proses perubahan struktural yang mendasari terjadinya HP, yaitu remodelling dari resistensi arteri pulmonal dan pengurangan jumlah pembuluh darah paru. Faktor utama terjadinya perubahan ini antara lain hipoksia alveolar kronis, vasokonstriksi, inflamasi kronis. ${ }^{5}$

Pada beberapa penelitian menunjukkan pasien dengan silikosis dan HP memiliki prognosis yang buruk. Faktor risiko yang berkaitan dengan tingkat mortalitas dan tingkat bertahan hidup pada pasien antara lain, mean artery pulmonary pressure (mPAP), gradien tekanan pulmonary vascular bed, PVR, saturasi oksigen arteri, dan volume ekspirasi paksa. Selain itu faktor risiko utama yang menentukan prognosis telah diketahui melalui metode diskriminatif yaitu volume ekspirasi paksa dan tekanan arteri pulmonalis. Perubahan fibrotik pada silikosis dikaitkan dengan tingginya kejadian HP, dan menurut klasifikasi HP saat ini, HP terkait silikosis dikategorikan kedalam HP terkait penyakit paru dan/atau terkait hipoksia. Tingkat keparahan HP biasanya berhubungan dengan tingkat keparahan penyakit paru yang mendasarinya, dan indikator paling umum adalah DLCO yang rendah dan $\mathrm{pCO} 2$ yang rendah. ${ }^{2}$

Pada kasus ini berdasarkan hasil CT scan toraks tampak konsolidasi dengan ukuran $\pm 7,9 \times 3,8 \times 5,6 \mathrm{~cm}$ di lobus superior paru kiri, dan $\pm 8,6 \times 3,3 \times 4,9 \mathrm{~cm}$ di segmen superior lobus inferior paru kanan. Gambaran ini kemungkinan merupakan bentuk dari complicated silikosis atau PMF. Sehingga cor pulmonale yang terjadi pada pasien ini diakibatkan oleh fibrosis paru terkait silikosis.

\section{Gejala Klinis}

Bentuk klinis silikosis dibagi berdasarkan intensitas, periode, dan riwayat paparan terhadap partikel silika, yaitu bentuk kronis, accelerated, dan akut.

\section{Silikosis kronis (klasik)}

Silikosis kronis dapat bersifat asimptomatik atau sesak saat aktivitas ataupun batuk yang progresif yang biasa dikaitkan dengan proses penuaan. Pada pemeriksaan radiologi dapat berupa gambaran opasitas kecil $(<10 \mathrm{~mm})$ biasanya pada lobus atas paru. Ciri patologis paru silikosis kronis adalah nodul silikotik. Nodul paru yang kecil pada silikosis kronis dapat menyatu dan berkembang menjadi complicated silikosis yang pada pemeriksaan foto toraks menghasilkan bayangan yang lebih besar $(>10 \mathrm{~mm}){ }^{8}$

Silikosis kronis umumnya muncul 10-15 tahun setelah paparan. Pada kasus yang lebih lanjut terdapat kerusakan struktural yang luas dengan membentuk masa fibrotik, dapat terjadi gagal napas dan cor pulmonale kronis. Pada fibrosis paru interstitial gejala utamanya adalah sesak napas. Temuan radiologi sangat mirip dengan idiopatik pulmonary fibrosis (IPF). Tidak banyak informasi tentang bentuk ini, tetapi penelitian terbaru melaporkan terdapat $11 \%$ kasus pneumoconiosis dengan temuan radiologi yang di anggap sebagai IPF. ${ }^{12}$

\section{Accelerated silikosis}

Accelerated silikosis terjadi akibat paparan yang lebih intens dan durasi yang lebih pendek (5-10 tahun) dari pada bentuk kronis, sementara gejala klinis, temuan radiografi, dan bentuk patologi paru hampir sama. ${ }^{8}$

\section{Silikosis akut}

Silikosis akut terjadi dalam beberapa bulan hingga 5 tahun setelah inhalasi silika dalam jumlah yang sangat banyak. Gejala utama yang sering muncul adalah sesak napas, penurunan berat badan. Perjalanan klinis biasanya sangat progresif dari gagal napas berat sampai kematian. ${ }^{8}$ Beberapa pekerjaan seperti sandblasting dan 
pengeboran batu telah terbukti menghasilkan partikel silika yang baru dan silikosis akut pada umumnya dikaitkan dengan pekerjaan tersebut. ${ }^{17}$

Pada kasus ini pasien sesuai dengan bentuk klinis silikosis kronis, karena pada foto toraks tampak nodul dengan ukuran $>1 \mathrm{~cm}$, dan gejala klinis yang muncul 15 tahun setelah paparan silika.

Gejala klinis hipertensi pulmoner berhubungan dengan derajat keparahan penyakit paru yang mendasari. Keluhan awal adalah mudah lelah atau sesak saat aktivitas, nyeri dada atau rasa tidak nyaman di dada yang sering dianggap penyakit lain. Gejala yang jarang terjadi adalah batuk kering, hemoptisis, suara serak (kompresi saraf laringeal rekuren kiri karena dilatasi arteri pulmonalis). Sinkop maupun nyeri kepala ringan saat aktivitas juga jarang terjadi namun merupakan tanda komplikasi hipertensi pulmoner yang buruk. Pada pemeriksaan fisik biasanya didapatkan gelombang besar yang dapat dideteksi pada denyut vena jugular.

Manifestasi klinis lainnya yang akan muncul bila terjadi kegagalan ventrikel kanan, antara lain edema ekstremitas bawah dan keluhan rasa tidak nyaman di perut, hepatomegaly, dan asites. Terdapatnya jari tabuh mengindikasikan suatu penyakit paru hipoksik kronik. ${ }^{7,19}$

Pada kasus ini pasien menunjukkan gejala klinis berupa sesak napas saat aktifitas, edemaa tungkai, asites, peningkatan JVP dan terdapat jari tabuh. Hal ini sesuai dengan gambaran klinis gagal jantung kanan disertai tanda hipoksia kronis.

\section{Diagnosis}

Diagnosis silikosis dapat ditegakkan berdasarkan riwayat pekerjaan yang terpapar oleh silika, temuan radiologis, serta menyingkirkan kemungkinan penyakit lain.

\section{Riwayat pekerjaan.}

Riwayat pekerjaan harus diketahui untuk memperkirakan adanya faktor risiko terhadap paparan silika. Beberapa hal yang harus diperhatikan antara lain, riwayat pekerjaan sebelumnya dan saat ini dan waktu terpapar silika, penjelasan terperinci tentang pekerjaannya, penggunaan alat pelindung diri, pengukuran debu untuk menentukan akumulasi risiko pajanan. $^{12}$

Pada kasus ini pasien memiliki riwayat pekerjaan di pabrik karet 15 tahun yang lalu. Pasien bekerja pada tahap pemotongan karet, pada proses ini menggunakan bahan talc yang ditaburi pada permukaan karet agar tidak lengket satu sama lain. Talc merupakan magnesium silikat yang terhidrasi yang terbentuk selama proses penghancuran batuan tremolit dan antrophyllite. ${ }^{20}$ Mineral yang umumnya ditemukan pada produk talc antara lain klorit, tremolite, antrophyllite, dan quartz..$^{21}$ Pasien diduga terpapar silika yang terkandung dalam talc, karena saat bekerja pasien jarang menggunakan alat pelindung.

\section{Pemeriksaan radiologi.}

\section{a. Chest X-ray}

Pemeriksan chest X-ray menunjukkan hasil opasitas reticuo-nodular bilateral di bagian atas paru, limfadenopati hilus dengan atau tanpa kalsifikasi eggshell. Nodul dapat berupa lesi seperti massa. Pada silikoasis sederhana chest $\mathrm{x}$-ray biasanya menunjukkan konsolidasi bilateral kecil atau konsolidasi berbentuk bulat di bagian atas paru, namun beberapa pasien menunjukkan bentuk fibrosis interstitial difus tanpa opasitas nodular yang khas. Gambaran radiologis pada pneumoconiosis telah dikategorikan oleh International Labour Organization (ILO) berdasarkan ukuran, bentuk dan jumlah, dan pada silikosis umumnya bentuk opasitas adalah tipe "q" dan " $\mathrm{r}$ ". ${ }^{15}$ Pada kasus ini pemeriksaan chest X-ray menunjukkan hasil opasitas nodular di hemitoraks kanan disertai infiltrat di paracardial kanan dan kiri.

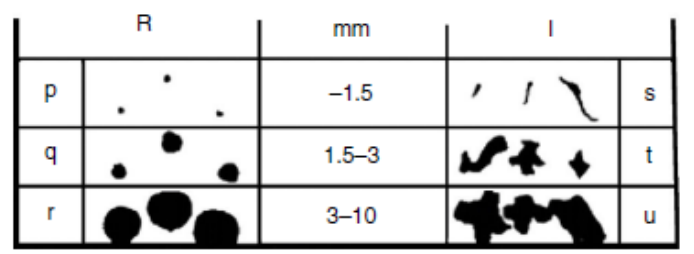

Gambar 3. Gambaran radiologi pneumoconiosis oleh International Labour Organization (ILO) berdasarkan ukuran, bentuk dan jumlah. R : bentuk bulat. I : bentuk irregular. ${ }^{12}$

\section{b. HRCT}

HRCT sangat penting dalam mengidentifikasi lesi yang mungkin tidak tampak pada chest-X ray. Studi menunjukkan bahwa HRCT lebih sensitif dalam mendeteksi gambaran spesifik pada silikosis seperti, perubahan nodular pada parenkim paru, bula, emfisema, mediastinal dan hilus. Parameter pada HRCT dapat digunakan secara tidak langsung dalam menilai gangguan fungsional pada silikosis. ${ }^{15}$ Pada PMF umumnya memiliki batas spiculated dengan emfisema di sekitarnya, serta memiliki densitas yang rendah dan area kalsifikasi karena nekrosis. ${ }^{12}$ HRCT biasanya menunjukkan konsolidasi bilateral di segmen posterior paru, nodul centrilobular dan ground-glass opacity. ${ }^{12}$ Pada kasus ini hasil pemeriksaan HRCT sesuai dengan gambaran silikosis.

\section{Tes fungsi paru}

Spirometry adalah pemeriksaan utama untuk menilai fungsi paru. Tes fungsi paru pada silikosis awalnya mungkin normal, namun dengan perkembangan penyakit dapat bersifat restriktif dan/atau obstruktif. Pada kasus lanjut atau progresif dapat terjadi penurunan FEV1, FVC, kapasitas total paru, dan kapasitas difusi. Obstruksi jalan napas dan penurunan kapasitas difusi dapat terjadi akibat fibrosis dan ketidaknormalan 
arsitektur paru. Beberapa penelitian menunjukkan bahwa penurunan fungsi paru dengan penurunan FVC dan FEV1 dikaitkan dengan besarnya pajanan, luasnya lesi radiologis dan riwayat tuberkulosis. ${ }^{12,17}$ Pada kasus ini hasil pemeriksaan fungsi paru menunjukkan restriksi sedang dan obstruksi ringan yang sesuai dengan tes fungsi paru pada silikosis.

\section{Histopatologi}

Pemeriksaan histopatologi paru pada silikosis menunjukkan nodul, warna bervariasi (abuabu,biru,hijau) ketika subjek terkena silika murni, bahkan bisa berwarna hitam atau merah (penambang batu bara). Lesi awal dapat terlihat nodular hingga agregat debu makrofag yang berada di sekitar kolagen. ${ }^{15}$ Nodul silikotik memiliki serat kolagen di tengah yang dikelilingi debu makrofag. Adanya granuloma, giant cell dan nekrosis harus dicurigai terkait tuberkulosis. ${ }^{9}$ Pada kasus ini hasil pemeriksaan histopatologi menunjukkan radang granumomatik yang lebih mengarah pada infeksi tuberkulosis.

\section{Bronchoalveolar lavage (BAL) dan sputum induksi}

BAL merupakan metode pemeriksaan yang memungkinkan pemeriksaan sel dan unsur terlarut dari saluran pernapasan bagian bawah untuk mempelajari mekanisme yang terlibat dalam patogenesis penyakit paru. Pada silikosis BAL dapat digunakan untuk mengidentifikasi paparan partikel silika, membantu mengidentifikasi mekanisme yang terlibat dalam patogenesis silokosis, menyingkirkan kemungkinan penyakit lain seperti TB dan kanker paru. ${ }^{22}$

Pemeriksaan sputum induksi merupakan metode yang sangat penting dalam pemeriksaan saluran napas yang terpapar molekul berat baik tingkat tinggi maupun tingkat rendah. ${ }^{9}$ Evaluasi pada pekerja yang terpapar silika dan logam berat mengungkapkan bahwa specimen BAL dan sputum induksi memberikan hasil kuantitatif dan kualitatif yang sama dalam hal analisis partikel kimia. Sputum induksi dapat mengidentifikasi lebih dari $30 \%$ sisa partikel terutama yang berdiameter 4-5 um yang berada saluran napas bagian bawah. ${ }^{23}$

Pada kasus ini kami tidak melakukan pemeriksaan spesimen BAL karena pasien memiliki risiko tinggi untuk tindakan FOB, sehingga kami memeriksa spesimen sputum induksi untuk mendeteksi adanya partikel silika pada saluran napas. Hasil pemeriksaan spektrofotometri pada spesimen sputum induksi menunjukkan silika sebanyak 108,96 ppm SiO2.

\section{Silikosis dan TB paru}

Hubungan antara silikosis dan TB paru telah lama diketahui, tetapi penelitian terbaru menunjukkan bahwa TB paru dapat terjadi pada individu yang pernah terpapar silika walaupun belum terdapat tanda-tanda silikosis. Risiko TB paru dan TB ekstra paru tetap ada seumur hidup meskipun paparan silika sudah berhenti, dan risiko akan jauh lebih besar pada pasien dengan silikosis akut dan accelerated silikosis. ${ }^{4}$ Silika menyebabkan gangguan pada respon imun paru, merusak fungsi makrofag, dan menyebabkan apoptosis makrofag. Dalam nodul silikotik diyakini dapat terjadi enkapsulasi basil M.tb yang menyebabkan reaktivasi tuberkulosis. Diagnosa akan sangat sulit ditegakkan pada TB paru yang tumpang tindih dengan silikosis, terutama pada manifestasi klinis tahap awal, ketika perubahan radiologis tidak dapat dibedakan karena silikosis yang sudah ada sebelumnya. Sebagai evaluasi tahap awal direkomendasikan pemeriksaan mikroskopis dahak, dan kultur dahak dari spesimen sputum induksi karena memiliki sensitivitas yang baik. ${ }^{24}$

Pada kasus ini pasien telah melakukan pemeriksaan sputum BTA dan geneXpert dari spesimen dahak spontan dengan hasil negatif, sehingga kami melanjutkan dengan pemeriksaan kultur M.tb dari spesimen sputum induksi dan masih menunggu hasil.

\section{Terapi}

Proses fibrotik pada silikosis bersifat irreversible, sehingga manajemen pasien lebih diarahkan untuk mencegah progresifitas penyakit dan komplikasi. Terapi kostikosteroid tidak memberikan manfaat jangka panjang pada pasien dengan silikosis kronis dan kemungkinan dapat meningkatkan risiko TB paru. Terapi simptomatik seperti antitusif dan mukolitik dapat diberikan untuk mengurangi gejala, anti biotik harus diberikan pada pasien dengan gejala infeksi saluran napas. Pemberian bronkodilator harus dipertimbangkan pada pasien dengan gejala obstruksi saluran napas. Pasien silikosis memiliki risiko tinggi infeksi TB paru, sehingga direkomendasikan untuk pemeriksaan tuberculin skin test dan interferon- $\gamma$ (IFN- $\gamma$ ) release assay (IGRA) untuk membuktikan adanya infeksi TB laten dan untuk pemberian profilaksis TB. Tindakan bilas paru yang ditujukan untuk menghilangkan silika dari paru saat ini belum terbukti bermanfaat dalam mencegah progresifitas silikosis akut maupun kronis., ${ }^{414}$

\section{RINGKASAN}

Seorang wanita umur 47 tahun dengan diagnosa cor pulmonale dan silikosis. Pasien memiliki riwayat pekerjaan di pabrik karet 15 tahun yang lalu selama 2 tahun. Pasien didiagnosa silikosis berdasarkan hasil pemeriksaan CT scan toraks dan pemeriksaan spektrofomerti dari spesimen sputum induksi. Perubahan 
fibrotik pada silikosis dikaitkan kejadian HP. Cor pulmonale merupakan perkembangan sekunder dari HP, yang ditandai oleh peningkatan resistensi pembuluh darah paru dan tekanan arteri pulmonalis yang menyebabkan peningkatan afterload ventrikel kanan, dan akhirnya menjadi kegagalan ventrikel kanan. Diagnosa cor pulmonale pada pasien ini berdasarkan gejala klinis, pemeriksaan EKG, echocardiography dan CT scan toraks. Komplikasi cor pulmonale pada kasus silikosis cukup jarang.

\section{DAFTAR PUSTAKA}

1. Devanathan S. Manual of Clinical Problems in Pulmonary Medicine, 5th Edition. Vol. 120, Chest. 2003. 692 p.

2. Zhang R, Ma G, Xu X, Liang L. Percutaneous treatment for silicosis-induced pulmonary artery stenosis. Medicine (Baltimore). 2018;97(2):e9469.

3. Higenbottam T. European Respiratory monograph. Pulmonary Hypertension. Hoeper M.M HM, editor. Norwich, UK: ERS; 2012.

4. Rees D, Murray J. Silica, silicosis and tuberculosis. Int J Tuberc Lung Dis. 2007;11(5):474-84.

5. Carbone RG. Pulmonary Hypertension and Interstitial Lung Disease Second Edition. Baughman R.P, Carbone R.G NS., editor. Switzerland: Springer; 2017.

6. Broaddus VC LRP effusion. I, Mason RJ, Broaddus VC, Martin TR K TE, Schraufnagel DE, Murray JF NJ. Medicine Murray \& Nadel' s Textbook of Respiratory Medicine. Philadelphia: Elsevier; 2016. 1719-1763. p.

7. Rasmin M, Chandra Putra A, Septiyanti D AMF, editor. Hipertensi Pulmoner. Edisi 2018. Jakarta: Perhimpunan Dokter Paru Indonesia; 2018.

8. Strohl K, Beall C, Netzer N. disorder of the pulmonary circulation. Fishman's pulmonary diseases and disorders 2015. 1412-20 p.

9. Anthony S, Taylor N. Occupational Lung Disorders. fourth edi. Taylor \& Francis Group; 2017.

10. Thomas CR, Kelley TR. A brief review of silicosis in the United States. Environ Health Insights [Internet]. 2010;4:21-6. Available from:
http://www.ncbi.nlm.nih.gov/pubmed/20523881\%0Ahttp://ww w.pubmedcentral.nih.gov/articlerender.fcgi?artid=PMC287 9610

11. Barber CM, Fishwick D, Carder M, Van Tongeren M Epidemiology of silicosis: Reports from the SWORD scheme in the UK from 1996 to 2017. Occup Environ Med. 2019;76(1):17-21.

12.Sahrun S, Koesoemoprodjo W, Permatasari A Pneumotoraks bilateral dan transaminitis non spesifik pada silikosis. Jurnal Respirasi 2018; 4(3):76-85.

13. Gaensler EA. Talco-Silicosis in a Rubber Worker. 1965;604:590-604.

14. Leung $\mathrm{CC}, \mathrm{Yu}$ ITS, Chen W. Silicosis. Lancet. 2012;379(9830):2008-18.

15. Sen S, Mitra R, Mukherjee S, K. Das P, Moitra S. Silicosis in Current Scenario: A Review of Literature. Curr Respir Med Rev. 2015;12(1):56-64.

16. Madl AK, Carosino C, Pinkerton KE. 8.22 Particle Toxicities. Heal (San Fr. 2010;

17. Greenberg MI, Waksman J, Curtis J. Silicosis: A Review. Disease-a-Month. 2007;53(8):394-416.

18. Fowler NO, Fowler NO. Chronic Cor Pulmonale. Diagnosis Hear Dis. 2011;268-82.

19. Klings ES, Editor S, Mandel J, Editor D, Finlay G. Cor pulmonale Cor pulmonale. 2013;5(2):1-9.

20. Waghmare M, Desai U, Joshi JM. Pulmonary talcosilicosis in a balloon making industry worker. J Krishna Inst Med Sci Univ. 2016;5(4):93-5.

21. Talc I. Talc not containing asbestiform fibres. IARC Monogr Eval Carcinog Risks to Humans. 2010;93:277317.

22. Moreira VB, Ferreira AS, Soares PJ, Gabetto JM, Rodrigues CC. The role of bronchoalveolar lavage in quantifying inhaled particle in silicosis. Rev Port Pneumol [Internet]. 2015;11(5):457-75. Available from: http://dx.doi.org/10.1016/S0873-2159(15)30522-5

23. Fireman E, Lerman Y. Induced sputum in occupational lung diseases. Breathe. 2016;2(1):50-9.

24. Barboza CEG, Winter DH, Seiscento M, Santos U de P, Terra Filho M. Tuberculose e silicose: epidemiologia, diagnóstico e quimioprofilaxia. J Bras Pneumol. 2008;34(11):959-66. 